\title{
Right ventricular blowout rupture complicating cardiopulmonary resuscitation in a patient with acute pulmonary embolism
}

\author{
Naoki Yonezawa 두, Tetsuhiro Takei, Michiko Fujisawa
}

Department of Emergency and Critical Care Medicine, Yokohama City Minato Red Cross Hospital, Yokohama, Kanagawa, Japan

\section{Correspondence to} Dr Naoki Yonezawa; nyone139@gmail.com

Accepted 27 July 2021

\section{DESCRIPTION}

A 79-year-old man collapsed during gait rehabilitation in the hospital on the ninth day after burrhole evacuation for chronic subdural haematoma. The medical emergency team was called and arrived $2 \mathrm{~min}$ later. The patient regained consciousness, but reported of dyspnoea and showed facial pallor with a feeble radial pulse. His blood pressure and oxygen saturation were unmeasurable. The ECG showed irregular tachyarrhythmia with complete right bundle branch block, and point-of-care transthoracic echocardiogram revealed right ventricular dilatation with a paradoxical septal motion at end systole. Based on these clinical findings, acute pulmonary embolism was suspected. Just $28 \mathrm{~min}$ after the collapse, the patient deteriorated to pulseless electrical activity, and manual cardiopulmonary resuscitation (CPR) was initiated.

He was transferred to the catheterisation laboratory, continuing chest compression with a mechanical device (LUCAS2; Physio-Control Operations, Scanfil Åtvidaberg, Åtvidaberg, Sweden). After $30 \mathrm{~min}$ of CPR, the establishment of venoarterial extracorporeal membrane oxygenation (ECMO) led to termination of chest compression. Subsequent pulmonary angiography demonstrated massive thrombi bilaterally in the main pulmonary arteries. Although aspiration mechanical thrombectomy successfully retrieved most of the thrombi, the ECMO flow was unstable at $1.0-1.7 \mathrm{~L} / \mathrm{min}$ with his haemoglobin level lowered from $13.0 \mathrm{mg} / \mathrm{dL}$ to $4.7 \mathrm{mg} / \mathrm{dL}$. Massive left intrathoracic fluid accumulation was identified by repetitive bedside ultrasonography. Massive blood transfusion for acute

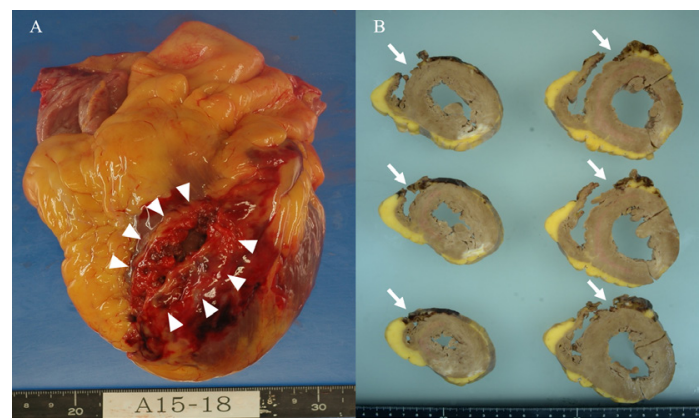

Figure 1 Macroscopic finding of the heart. (A) External view (arrowheads) and (B) axial slices (arrows) showing longitudinal laceration approximately $7 \mathrm{~cm}$ in length along the interventricular septum, with the laceration turning outward.

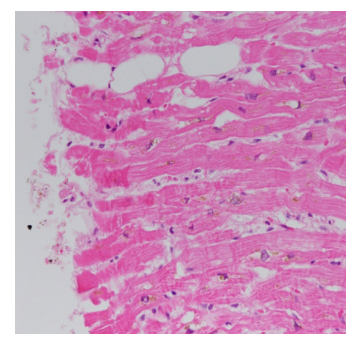

Figure 2 Histologic examination at the rupture site of the right ventricle showing no myocardial ischaemic changes.

haemorrhage was performed, but the patient died 4 hours after cardiac arrest.

At autopsy, multiple rib fractures (the right third and the left second and third), a left haemothorax with an intercostal artery injury and right ventricular rupture with haemopericardium and pulmonary artery trunk distention, were observed. No pericardial injuries or perforations were found. The right ventricle showed normal thickness, but a transmural longitudinal laceration approximately $7 \mathrm{~cm}$ in length was located along the interventricular septum, with the laceration turning outward, indicating a blowout-type rupture (figure 1). Histologic examination showed no vulnerability, such as ischaemic change, in the myocardium at the rupture site of the right ventricle (figure 2).

Cardiac rupture, which occurs in $0.6 \%$ of CPRtreated patients, is fatal and mostly associated with thoracic wall injuries, including rib or sternal

\section{Learning points}

Cardiac rupture is a rare, fatal complication of cardiopulmonary resuscitation (CPR). Most cases are associated with thoracic wall injuries, including rib or sternal fractures, or myocardial ischaemia.

- CPR-associated right ventricular rupture independent of these factors can occur in the setting of acute massive pulmonary embolism. The possible mechanism in this case was the excessive increase in right ventricular pressure during chest compression concurrent with the obstruction of right ventricular outflow.

- The right ventricular wall adjacent to interventricular septum is vulnerable to the increase in intracardiac pressure. 
fractures, or myocardial ischaemia that usually occurs in the left ventricle. ${ }^{1}$ The present case reported a rare CPR-associated right ventricular rupture independent of these factors. The possible mechanism of the right ventricular rupture in this case was the increase in intracardiac pressure due to chest compression in the setting of acute massive pulmonary embolism. ${ }^{23}$ Direct compression of the right heart during chest compression, concurrent with the obstruction of right ventricular outflow due to giant thrombi, may produce excessive intracardiac pressure. This excessive pressure may, in turn, result in the blowout rupture at the most vulnerable lesion of the right ventricular wall, the area adjacent to the interventricular septum. ${ }^{24}$

Contributors NY, TT and MF examined and treated the patient. NY drafted the article. TT and MF designed and supervised the study. All authors contributed substantially to the data acquisition and to editing, revising and finalising the article before submission. All authors approved the final manuscript.
Funding The authors have not declared a specific grant for this research from any funding agency in the public, commercial or not-for-profit sectors.

Competing interests None declared.

Patient consent for publication Obtained.

Provenance and peer review Not commissioned; externally peer reviewed.

\section{ORCID iD}

Naoki Yonezawa http://orcid.org/0000-0003-2557-5698

\section{REFERENCES}

1 Miller AC, Rosati SF, Suffredini AF, et al. A systematic review and pooled analysis of CPR-associated cardiovascular and thoracic injuries. Resuscitation 2014;85:724-31.

2 Hickey TBM, Gill GGK, Seidman MA, et al. CPR-associated right ventricular rupture in the setting of pulmonary embolism. CJEM 2016;18:484-7.

3 Baldwin JJ, Edwards JE. Clinical conference: rupture of right ventricle complicating closed chest cardiac massage. Circulation 1976;53:562-4.

4 Kempen PM, Allgood R. Right ventricular rupture during closed-chest cardiopulmonary resuscitation after pneumonectomy with pericardiotomy: a case report. Crit Care Med 1999;27:1378-9.

Copyright 2021 BMJ Publishing Group. All rights reserved. For permission to reuse any of this content visit

https://www.bmj.com/company/products-services/rights-and-licensing/permissions/

BMJ Case Report Fellows may re-use this article for personal use and teaching without any further permission.

Become a Fellow of BMJ Case Reports today and you can:

- Submit as many cases as you like

Enjoy fast sympathetic peer review and rapid publication of accepted articles

Access all the published articles

Re-use any of the published material for personal use and teaching without further permission

Customer Service

If you have any further queries about your subscription, please contact our customer services team on +44 (0) 2071111105 or via email at support@bmj.com.

Visit casereports.bmj.com for more articles like this and to become a Fellow 